\title{
10 歳以下の癒着型真珠腫に対する鼓室形成術
}

\author{
児玉 章・細川 誠二・足守 直樹 \\ 山元理恵子・岩渕 史郎*
}

\section{Tympanoplasty for Adhesive Type Cholesteatoma in Young Children}

\author{
Akira Kodama, Seiji Hosokawa, Naoki Ashimori and Rieko Yamamoto \\ (Numazu City Hospital) \\ Shirou Iwabuchi \\ (Ami ENT Clinic)
}

\begin{abstract}
Tympanoplasty with canal reconstruction was performed on 16 ears with adhesive type cholesteatoma from 15 children of less than 10 years old during 1998-2002. A staged operation was performed in 14 ears and one-staged in two ears.

Our postoperative results of tympanoplasty in the patients were satisfactory as follows.

There was no recurrence of cholesteatoma in 15 of the 16 ears. In only one ear an extremely small pearl-like residual cholesteatoma was easily removed in a second operation. Also there was no recurrence of adhesion of the tympanic membrane in 15 ears, except for one ear in which partial adhesion still existed after a second operation.

Thus, tympaoplasty for adhesive type cholesteatoma in young children seems to be useful for preventing the recurrence of cholesteatoma, and for the restoration of the adhesive tympanic membrane to the normal position.
\end{abstract}

Key words : tympanoplasty, adhesive type cholesteatoma, young children

\section{はじめに}

近年，当院では小児の癒着性中耳炎よりさらに病変が 進行した癒着型真珠腫の治療をする機会が増える傾向に ある. 最近の 5 年間に 10 歳以下の小児の癒着型真珠腫 15 例 16 耳に手術を行った。一般的に, 成人の癒着性中 耳炎や癒着型真珠腫に対する手術成績はあまりょくない といわれている。しかし，今回の小児のみを対象にした 手術成績は比較的良好な結果が得られたので，われわれ の手術における術前, 術中, 術後の具体的な治療方針と その術後成績について報告したい。

\section{対象と方法}

今回対象とした癒着型真珠腫とは鼓室内側壁に陥入瘉 着した鼓膜上皮が周囲の中耳にさらに深く進入し，耳鏡 所見では癒着鼓膜の底部の全貌が広い範囲で観察できな いものと考えた.この定義に当てはまり手術を行ったも のは，平成 10 年 1 月から平成 14 年 12 月までに 10 歳以 下では 15 例 16 耳みられた。年齢分布は $3 \sim 10$ 歳であ り，男児 13 例で女児 2 例であった（図 1 )。これらの 15 例 16 耳について, 当科受診までの経過, 鼓膜所見, 側頭 骨 CT および手術所見, 術後成績などについて検討した. 今回の対象からはまだ癒着性中耳炎に止まっているもの 


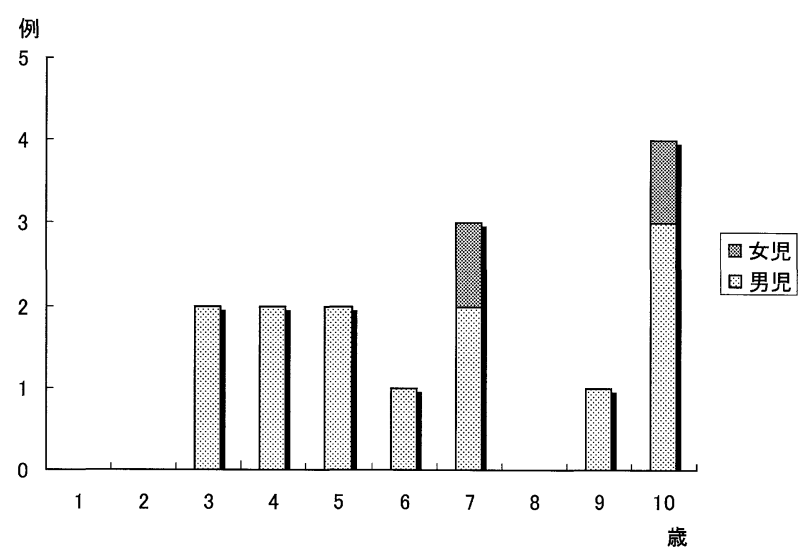

図 110 歳以下の小児癒着型真珠腫の年齢分布

は除外した.

癒着型真珠腫に対し，以下のような方針で治療をすす めた.

術前：(1)診断確定日よりなるべく早い時期に第 1 回目 の手術を行う．（2)原則的に鼓膜チューブを挿入して，真 珠腫の進行を防ぐとともに, 中耳腔の含気化を促すよう にする，しかし，外耳道が狭い，癒着範囲が広く挿入で きる鼓膜面がほとんどない，患児が動くなどの技術的困 難さもあり実際に術前に鼓膜チユーブが挿入できたのは 16 耳中 8 耳であった。 しかも，市販の短期型鼓膜チュー ブを挿入できたのは 1 耳のみで，他の 7 耳には乳児用の アトム栄養チューブ®の $4 \mathrm{Fr}$ を約 $10 \mathrm{~mm}$ の長さに切り, これを鼓膜チューブとして挿入した. 挿入期間は $1 \sim 4$ カ 月であった。 (3)鼻炎や副鼻腔炎を伴った患児には積極的 に局所および全身の消炎治療を行う。

術中：(1)外耳道を十分拡大し, 中・下鼓室の操作が明 視下に行えるようにする. (2)真珠腫が上鼓室や乳突洞に 進入している場合は，進入範囲に応じて上鼓室や乳突洞 を開放し，真珠腫を一塊摘出し中鼓室と上鼓室〜乳突洞 との間に十分交通をつける ${ }^{11}$. 病変除去後, 外耳道再建 型鼓室形成術を行う。再建材料は 1 回目の手術では乳突 部から採取した薄い骨板を使用する ${ }^{1)}$. (3)術前に挿入さ れていた鼓膜チューブがあれば，いったん除去し, 癒着 の範囲が狭い場合は短期型を, 範囲が広い場合は長期型 の新しい鼓膜チューブを鼓膜の最適な位置に再挿入し て, 中耳の含気化を促す. (4)手術は比較的病変が軽く 1 回の手術で真珠腫上皮が完全摘出できた 2 耳を除いた 14 耳は 2 段階手術を行った. 1 回目の手術から $6 \sim 10$ カ月 以内に 2 回目の手術を行い, 真珠腫の遺残, 再発の有無
を確認する. 2 回目の手術も外耳道再建型鼓室形成術を 行い，再建材料は形をトリミングしやすい耳介より採取 した軟骨を使用した ${ }^{11}$. この時も原則的に新しい鼓膜 チューブに入れ替える.

術後 : (1) 1 回目も 2 回目の術後も月に $1 \sim 2$ 回の定期 的な経過観察を行う. (2)鼓膜内陥癒着の再発の防止に最 大限の注意を払い, 必要があれば閉塞や脱落など無効之 なったチューブを摘出し, 新しいチューブの再挿入を積 極的に行う。この際, 外来での挿入が困難な場合は, 全 身麻酔下にチューブ挿入も考える. (3)しかし，術後鼓膜 チューブが自然脱落した後, 中耳や鼓膜が安定した状態 が続けば，チューブの再挿入は行わず，定期的な観察を 行う. (4) 1 回目の手術後あるいは 2 回目の手術前に耳の CT検査を行い1回目の手術前のものと比較して, 1回目の 手術の中耳の含気状態を調べ, 2 回目の手術の参考とす る. CT 検查はウィンドウ幅 4000 と同じだが, ウィンド ウレベルが+ 400 とー 400 の違った条件で撮影した 2 組 の軸位断 CT 写真について検討をした。

\section{結果}

1. 当科受診までの経過

既往歷によると，過去に渗出性中耳炎として他院ある いは当院にて通院期間はまちまちだが治療歷があり, 沴 出性中耳炎から癒着性中耳炎, さらに癒着型真珠腫へと 移行したと考えられる症例が 15 例中 9 例に認められた. 9 例中 2 例は当初は当院での治療歴のある症例であった. 1 例は 1 歳から 2 歳過ぎまで約 1 年間以上，もう 1 例は 2歳頃数回当院で渗出性中耳炎として治療されていた.し かし, その後 2 例とも来院しなくなり, 他院で治療継続 していたとのことであるが, 前者が 7 歳と後者が 6 歳に なって真珠腫の疑いで当院に紹介された症例であった. 他の 3 例は他院で滲出性中耳炎の通院治療中に病変が進 行し, 癒着性中耳炎から癒着型真珠腫への移行が疑われ たため当科に紹介された症例であった. 残りの 4 例（当 院の 2 例と他院の 2 例）は患者の都合により途中で渗出 性中耳炎の治療を中断し, 再受診した時には癒着型に移 行していた症例である. 中断期間は短いもので 3 月, 長 いもので 4 年であった．その他の 6 例は当科受診前には 滲出性中耳炎の治療の既往歴のない症例であった。 その なかの 3 例は耳漏の出現 (2 例), 耳に盛んに手を持って いく(1 例)など何らかの耳症状がみられるようになった ため当科を受診した症例であった．残りの 3 例は特に耳 
部分内陥癒着

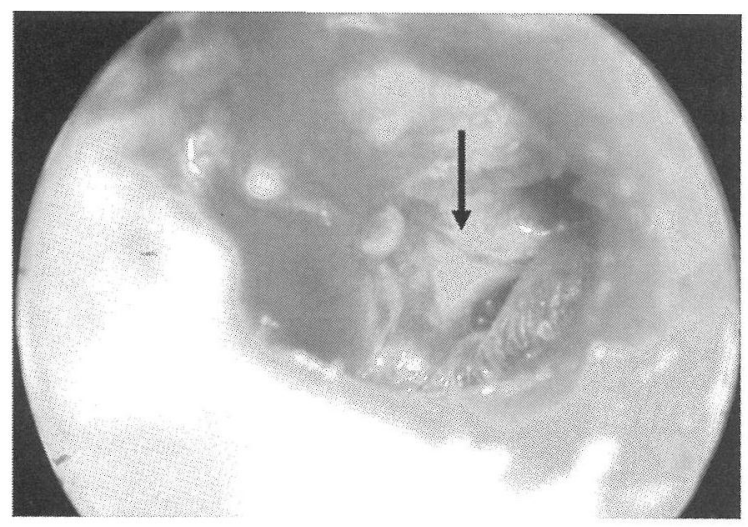

A

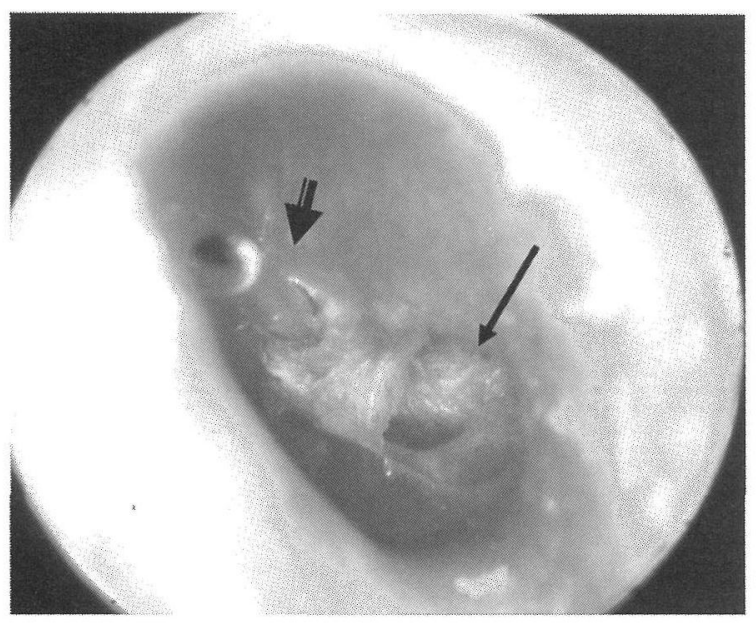

B
広範内陷癒着

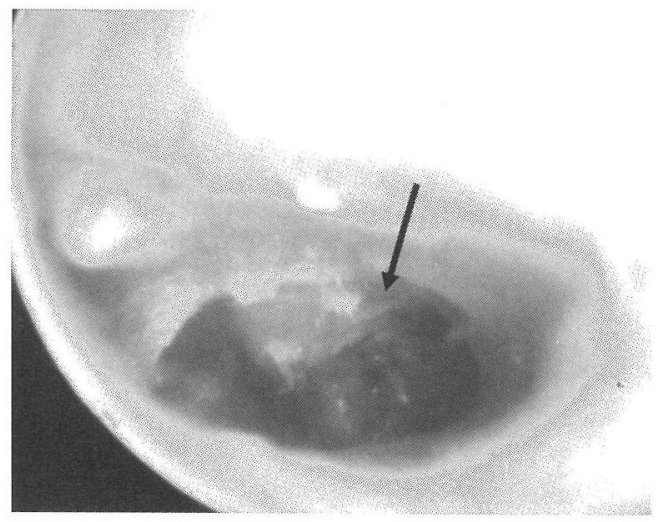

C

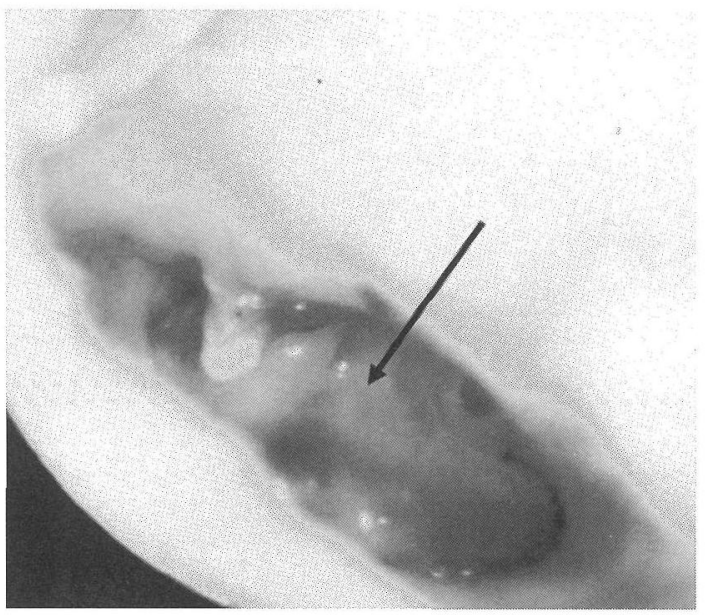

D

図 2 部分内陥癒着と広範内陥癒着の各 2 例の術前鼓膜所見

部分内陥癒着の症例 A（3 歳，男児）と広範内陥癒着の C (7 歳，男児）は真珠腫上皮が中〜上鼓室移行部までの進入であった。 一方, 症例 B（3 歳, 男児）は鼓膜の内陥範羋が狭いが, 真珠腫上皮は上鼓室天蓋まで, 全面癒着の D（10歳，女児）は真珠腫 が乳突洞まで進入していた。細矢印：内陥癒着鼓膜，太矢印：自家製の 4 Fr サイズの細長い鼓膜チューブ。

の症状の訴えはなかったが，2 例は学校検診で鼓膜異常 が指摘され当科紹介となり，他の 1 例は他院より慢性副 鼻腔炎とアデノイド増殖症で当科に紹介され，癒着型真 珠腫がみつかった症例であった。

2. 鼓膜所見

鼓膜の内陥と癒着の範囲によって，鼓膜全体の半分以 下を部分内陥瘉着型, 半分以上を広範内陥癒着型の 2 つ に分類した（図 2)。前者が 16 耳中 5 耳，後者が 11 耳で あった。広範内陥癒着型のなかの 1 耳は程度が特にひど く鼓膜の全面癒着の所見であった。当科初診時，鼓膜の 内陌癒着以外鼓膜所見は, 部分内陥癒着型では穿孔を
伴っていたものはなく，耳漏は 1 耳にみられた。広範内 陷癒着型では 1 耳に内陷癒着の一部に小穿孔が， 3 耳に 耳漏がみられた。今回対象となった 15 例の対側耳の鼓膜 所見は部分癒着型では 5 耳中 3 耳は滲出性中耳炎を伴っ ており，広範癒着型では 10 耳中 5 耳に滲出性中耳炎， 1 耳に癒着性中耳炎，1 耳に癒着型真珠腫の所見がみられ た。

3. 1 回目の手術所見

部分内陥癒着型（図 3）では，真珠腫の進展範囲は 5 耳とも卵，正円空などの鼓室後部に真珠腫が進入してお り，そのなかの 3 耳は鼓室洞に深く進入していた。上方 


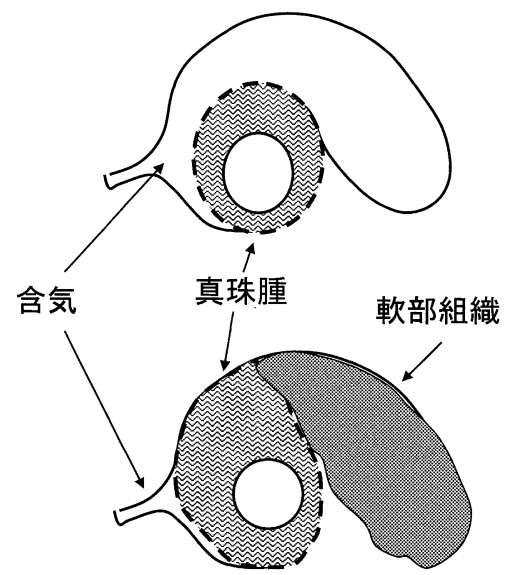

4耳

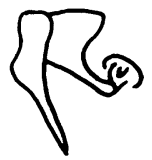

3耳

1 耳

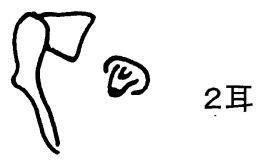

図 3 部分内陥瘉着の真珠腫進展範囲と中耳病変

5 耳中 1 耳に真珠腫は上鼓室天蓋まで進展しており, 含気腔は耳管鼓室口にのみみられた. 2 耳にキヌタ骨長脚の消失がみられ た. 真珠腫範囲内の白抜きは鼓膜内陥入口部を示す.

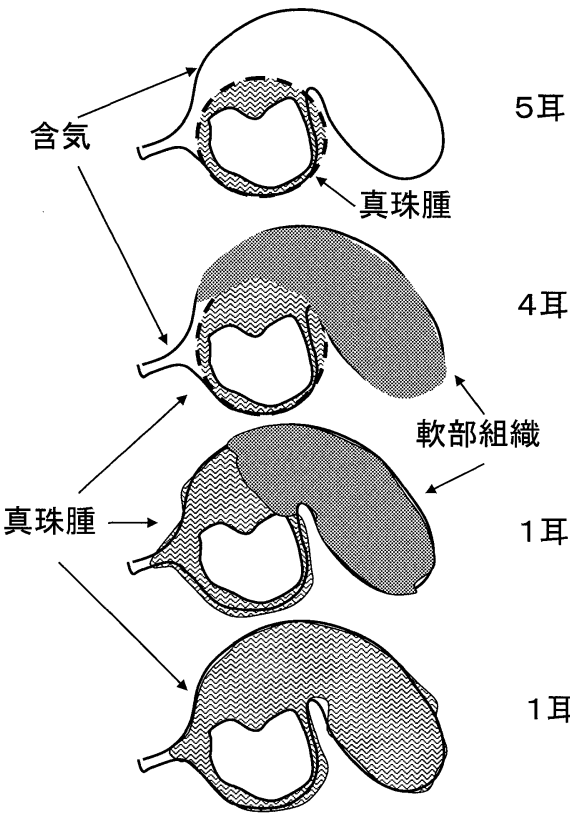

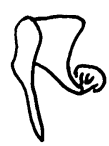

9耳

4 耳
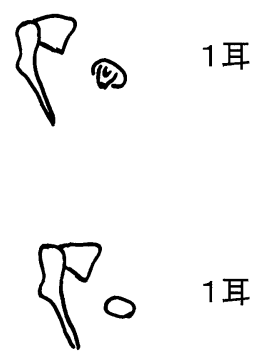

図 4 広範内陥癒着の真珠腫進展範囲と中耳病変

11 耳中 9 耳は真珠腫がまだ上鼓室深く進入していなかった。しかし，含気腔はすでに 11 耳中 6 耳に上鼓室および乳突洞にはみ られなかった. 耳小骨は 2 耳にキヌタ骨長脚あるいはアブミ骨上部構造の消失がみられた. 真珠腫の範囲内の白抜き: 鼓膜内陌 入口部.

へは 5 耳中 4 耳が上〜中鼓室の境界付近にまで進入して おり, 残りの 1 耳は上鼓室に充満し, さらに上鼓室天蓋 まで進入していた. 耳小骨病変については，5耳中 3 耳 は耳小骨連鎖が保たれていたが，残りの 2 耳はキヌタ骨 長脚の消失がみられた。
広範内陥癒着型（図 4) では真珠腫の進展範囲は11 耳 全耳が中・下鼓室の内側壁に広い範囲で癒着しており, なかでも 11 耳中 9 耳は卵円空, 正円空へ深く真珠腫が進 入し，さらにそのなかの 6 耳はさらに哚く鼓室洞にまで 進入していた. 上方へは中〜上鼓室の境界周囲まで進入 
していたのが 9 耳と多くみられたが，残りの 2 耳のうち 1 耳は上鼓室天蓋まで，他の 1 耳乳突洞深く進入して いた。前方へは 3 耳が耳管鼓室口にも深く進入していた が，症例により差はみられるものの，耳管粘膜と小さな 含気腔は保たれていた。広範癒着型では，耳小骨連鎖が 保たれていた症例が 11 耳中 9 耳で, キヌタ骨長脚の消失 が 1 例，キヌタ骨長脚とアブミ骨上部構造の消失が 1 例 であった。以上のように真珠腫の進展範囲は広範内扸癒 着型の方が部分内陷癒着型よりやや広い傾向がみられる ものの，手術で真珠腫上皮を摘出する上で厄介な鼓室後 部への進展の程度や耳小骨の影響の程度は両者にほとん ぞ大差はなく，鼓膜所見から真珠腫病変の進展範团を予
測することは困難であった。

手術で真珠腫上皮を摘出する上で重要な真珠腫上皮の 性質は部分内樎癒着型々広範内陥癒着型でもほぼ同様 で，上皮は薄く破扎やすいが癒着部を除いて周囲は肥厚 した中耳粘膜がまだ残っている場合が多く，また，粘膜 之真珠腫上皮の間に粘稠な貯留があるため比較的剥離し やすく，周囲の粘膜を保存することが可能であった。

4. 1 回目と 2 回目の手術前の CT 所見

1 回目の手術前の CT 所見では，部分内陥癒着型の中 耳の含気状態は，症例によって差はみられるものの 5 耳 中 4 耳は中・上鼓室さらには乳突洞に含気腔は残ってい た。しかし，真珠腫が上鼓室に充満していた 1 耳は耳管
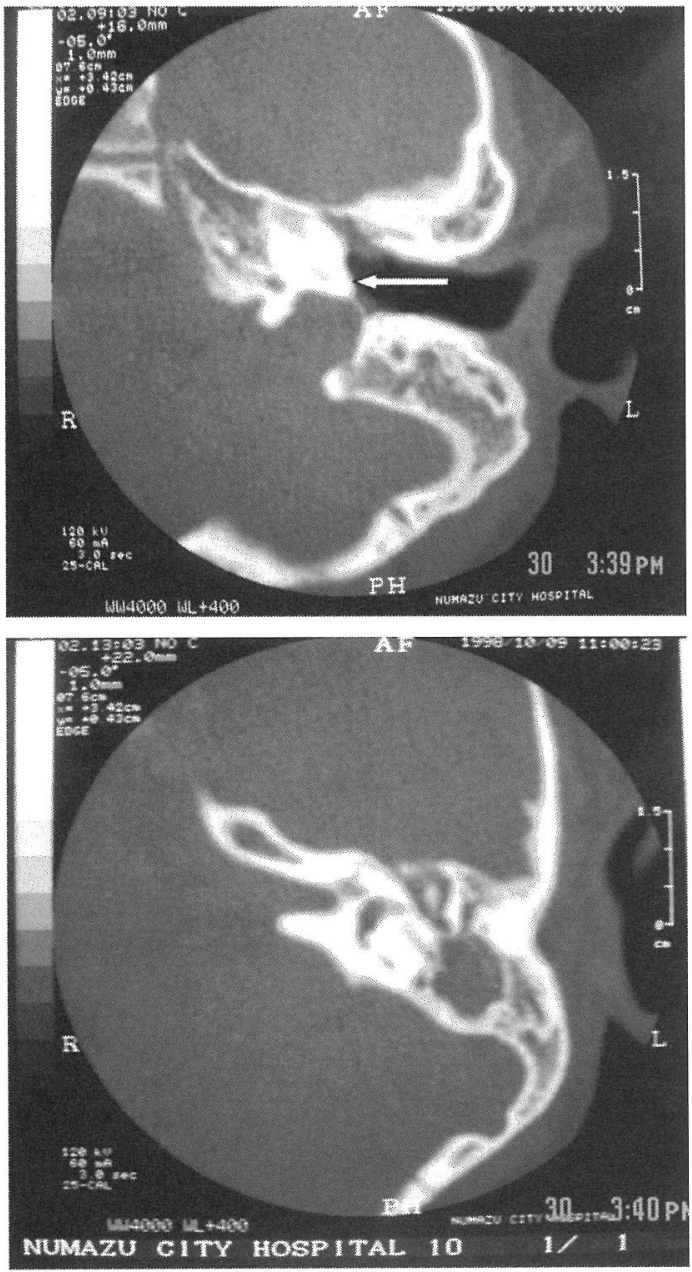

術前 CT
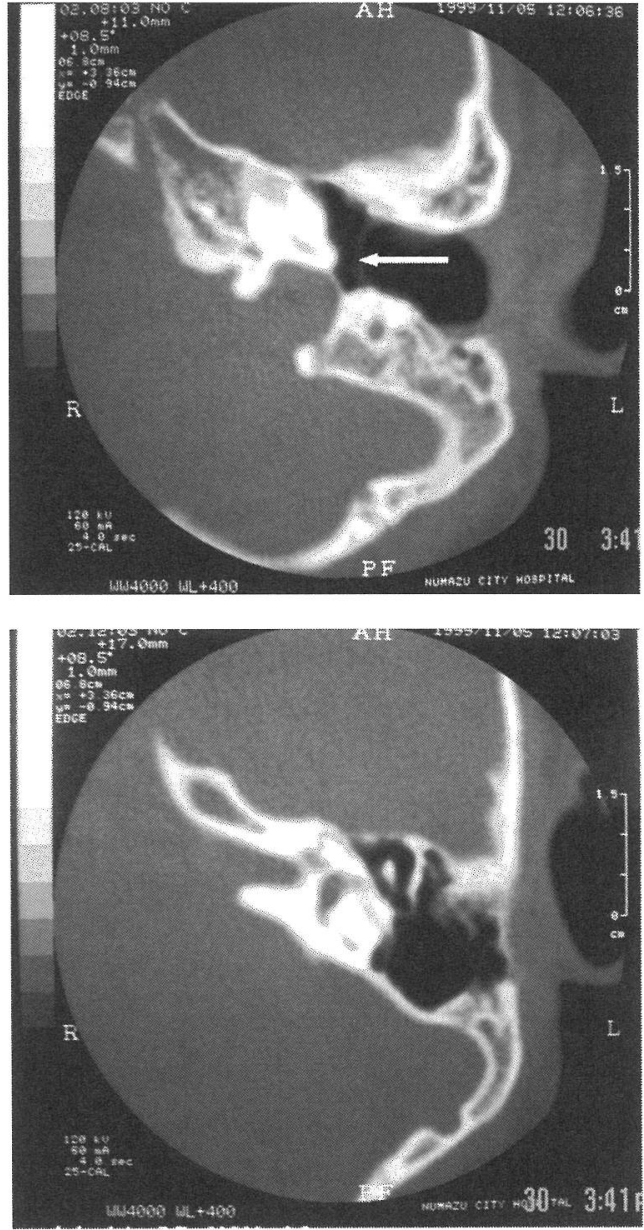

術後 CT

図 5 術前・術後の CT 所見

広範内陥癒着型の鼓膜（7 歳，男児）は術後に正常の位置に戻り（矢印），中・上鼓室さらに乳突洞の含気化む良好である 
鼓室口以外には含気腔はみられず，乳突洞および蜂巣は 軟部組織陰影で充満していた。広範内陷癒着型の中耳の 含気状態は, 11 耳中 5 耳は鼓室から乳突洞まで含気腔が 残っていた. 残りの 6 耳は中耳腔のいずれにも含気腔は 認められなかったが，そのなかの 3 耳の耳管鼓室口にわ ずかに含気腔が認められた。手術所見を参考に CT 所見 を見直してみても CT 写真からは中耳の含気や軟部組織 陰影の状態はわかるが真珠腫の進展範囲を予測すること は困難であった。

2 回目手術前の CT 所見では鼓膜の広範内陥癒着があ り, 真珠腫が上鼓室から乳突洞間で充満していた病変が 最も高度であった症例 1 例を除いていずれの症例も乳突 洞も含めた中耳腔の含気化は良好であった（図 5).

5. 2 回目の手術所見と術式

部分内陷癒着型も広範内陥癒着型も 1 例を除いて，他 は CT 所見と同様に, 鼓室から乳突洞にかけての含気化 は良好であった（図 6).

2 回目手術の時，小さなパール状の遺残性の真珠腫が みられた 1 耳を除いて他の 15 耳は真珠腫の遺残・再発は 認めなかった。両型の術式（表 1）に大きな差はみられ ず，鼓室形成術 I 型が多く行われた，真珠腫の進展範囲 および耳小骨病変の程度によって，部分内陌瘉着型では 外耳道再建を行った症例が 2 耳, 耳小骨連鎖再建（鼓室 形成術 III c，IV c 型） 1 耳ずつ，広範内陥癒着型では，外
耳道再建を 8 耳，耳小骨再建を 7 耳に行った。

5. 2 回目手術の術後成績

2 回目の手術を終了して 1 年 3 カ 月から 6 年経過してい るが，今のところ再発性および遺残性真珠腫は 1 例むみ られていない，広範内陥癒着型のなかで，鼓膜が全面癒 着し上鼓室から乳突洞まで真珠腫が進入していた最も高 度な病変がみられた 1 例は，術後に鼓室後部に再癒着が みられた。しかし，他の全例の鼓膜所見はいずれの症例 も鼓膜はほぼ正常化していた（図 7).

術後聴力については, 2000 年日本耳科学会の判定基準 では聴力が測定できた 15 耳中 11 耳は術後聴力が $30 \mathrm{~dB}$ 以内に， 2 耳は気導骨導差が $15 \mathrm{~dB}$ 以内となり，15 耳中 13 耳 $(87 \%)$ が成功となった。 なお，術前 3，4 歳で正 確な聴力検查ができなかった小児もすでに術後 $2 \sim 3$ 年 経過して信頼できる検查も可能となり, 術前検査の比較 といらより術後の聴力で $30 \mathrm{~dB}$ 以内, 気導骨導差 $15 \mathrm{~dB}$ の判定基準で成功か不成功かを判断した。

\section{考 察}

幼小児期の滲出性中耳炎は遷延化すると，その一部は 癒着性中耳炎, さらには癒着型真珠腫に進展すると考元 られている2 ${ }^{4)}$. 癒着性中耳炎と癒着型真珠腫との境界 は必ずしも明確に区別されておらず，報告者によって意 見が分かれている2)516)。われわれは，鼓膜が鼓室内側壁

\section{部分内陥癒着 5 耳}

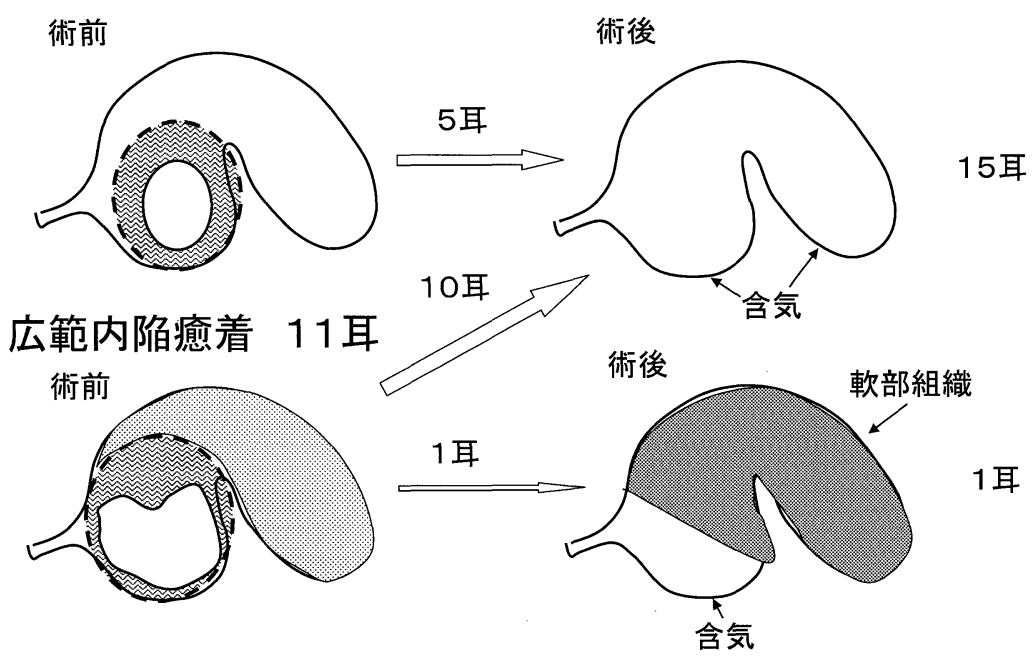

図 6 部分内陥瘉着と広範内陥癒着の術後の中耳の含気状態 部分および広範内陷癒着を含めた 16 耳中 15 耳は中耳腔の含気化は良好であった。鼓膜の全面癒着がみられ，真珠腫が乳突洞ま で充満して抢り，最も病変の高度であった 1例のみ術後鼓膜後上部に再癒着がみられた。 


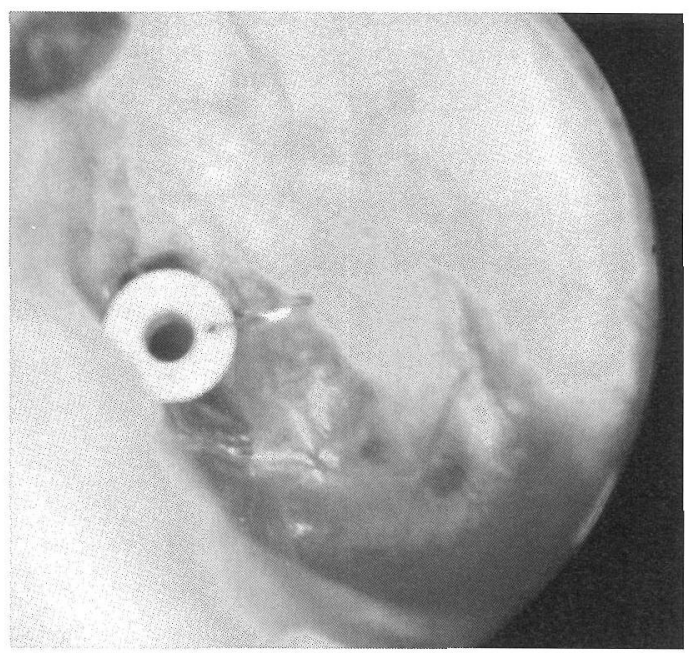

A

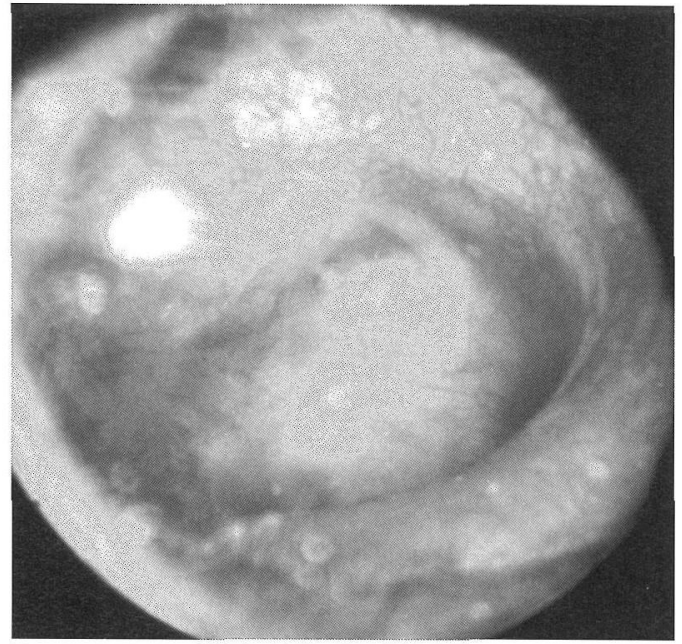

B

図 7 術後の鼓膜所見

術前に部分（A：3 歳，男児）および広範内陥癒着（B：7 歳，男児）のみられた症例の鼓膜はほぼ正常化している. A の男児は 術後 4 年経過しているが滲出性中耳炎を反復するため鼓膜チューブの再挿入を繰り返している．B は術後すでに 2 年 9 月月経過 しており，6カ月の時点でチューブは脱落抜去となるがその後鼓膜は安定しており経過観察中である.

\section{表 1}

\begin{tabular}{|c|c|}
\hline \multicolumn{2}{|c|}{ 部分内陥癒着に対する術式 } \\
\hline I 型 & 3 耳 \\
\hline 外耳道再建 IIIC 型 & 1 耳 \\
\hline 外耳道再建 IVc 型 & 1 耳 \\
\hline \multicolumn{2}{|c|}{ 広範内㫟癒着に対する術式 } \\
\hline I型 & 6 耳 \\
\hline 外耳道再建 I 型 & 1 耳 \\
\hline 外耳道再建 IIc 型 & 2 耳 \\
\hline 外耳道再建 IIIC 型 & 1 耳 \\
\hline 外耳道再建 IVc 型 & 1 耳 \\
\hline
\end{tabular}

に内陥癒着し，陥凹の底部がほぼ観察できるものを癒着 性中耳炎と考えた。一方，癒着型真珠腫は $\operatorname{Tos}^{2)}$ が述心゙ ているように癒着性中耳炎がさらに進展したもので，中 耳内側壁に癒着陥入した底部が広い範囲でみえず，上皮 が鼓膜やツチ骨の内側に入り込み，鼓室後部や中〜上鼓 室の方向に深く進入したものと考えた。癒着型真珠腫は 鼓膜緊張部が癒着するため緊張部型真珠腫ともいわれて いる5 7)

今回の症例において 15 例中, 耳鼻咽喉科受診歴のある 9 例は最初は滲出性中耳炎の所見であったが，中耳炎の 遷延化により癒着性中耳炎から癒着型真珠腫にいたった ものであった。また同一症例で両側に癒着型真珠腫がみ
られた 1 例を除いた 14 耳中 9 耳は対側耳に滲出性または 癒着性の中耳炎を伴っており，この病態がさらに遷延化 すると癒着性中耳炎や瘉着型真珠腫に移行する可能性が 考えられた。

ところで，成人の癒着性中耳炎や癒着型真珠腫に対す る手術成績はよくないといわれている8) 10)。これらの中 耳炎に対して手術成績が上がらない主な原因は，中〜上 鼓室，乳突洞さらには耳管鼓室口周囲など広い範囲にわ たって含気腔および粘膜上皮の欠損，分厚い肉芽組織の 充満など高度の陳旧性病変がみられること11) と関係して いると考えられる。手術で含気腔のある中耳を再建して も，中耳に粘膜上皮がほとんどないため術後肉芽組織 の再増殖があり，高率に鼓膜が再癒着する。現在，諸 家12) 14) によりさまざまな工夫がなされ術後成績の向上 が計られつつあるが, 必ずしも満足のいく成績が得られ ていないのが現況である。

今回の小児の癒着性真珠腫でも部分内陷癒着型 5 耳中 1 耳 $(20 \%)$ 己広範内陥癒着型 11 耳中 6 耳（55\%）は中 耳の大部分に含気腔は認められず，また，卵円空窩，正 円空窩，鼓室洞，下鼓室蜂巣さらに耳管鼓室口にも上皮 の進入がみられた点などは成人のそれに類似する所見も 多くみられた。それにもかかわらず，良好な結果を得る ことができたのはなぜだろらか。進入した上皮や周囲組 
織，中耳に充満する軟部組織の性状には成人のものと比 べかなり違いがみられた．進入した上皮はきわめて薄く 皮下組織や肉芽の増殖などの炎症所見はあまり伴ってお らず，また鼓室内側壁の癒着中心部を除いて瘉着の程度 は成人ほど高度ではなく，進入上皮の周囲にまだ粘膜上 皮や貯留液を伴った間隙が残っているため，真珠腫上皮 は比較的剥離しやすいことが特徴であった。

一般に幼小児の癒着性中耳炎あるいは癒着型真珠腫は 耳漏を伴っていないことが多く，また聴力低下などの症 状も比較的少ない，そのため手術をするタイミングが難 しく，必ずしもただちに手術しなくてもよいという考え 方もよく聞かれる。しかし，われわれは以下のような理 由で成人型のように病変がまだ陳旧化していない幼小児 期に積極的に手術を行ってきた. 1) 小児では症例によっ て鼓膜や CT 所見などの検查で真珠腫病変の範囲の予測 は難しい，そのため保存的な経過観察では病変の進行度 を正確に判断することは困難で，時に病変を過小評価す る危険性を伴うと思われる。実際に今回の症例の CT 検 查や鼓膜所見でも予測が難しく，真珠腫の進展範囲が高 度のものもみられた，2）成人と違って幼小児は中耳炎を 起こしやすく，真珠腫病変がさらに急速に増悪する危険 性がある．3）成人と比べて中耳病変がまだ比較的軽度 で，真珠腫病変周囲に貯留液を伴ったスペースがあり， 中耳粘膜が残っていることが多い，4）真珠腫上皮は卵円 空，正円空，鼓室洞などに深く進入していても比較的癒 着の程度が軽く，破らずに一塊として摘出できることが 多い。この性質は比較的小さいうちに発見された先天性 真珠腫が周囲組織と比較的癒着が少なく剥離しやすいこ とと似ており, 今回の 2 回目の手術では真珠腫の遺残が 少なかったことに関係していると思われる.

以上のような理由で，幼小児のまだ可逆的病変である と考えられる早い時期，そして成人型の癒着性中耳炎や 癒着型真珠腫に移行する前に手術を行うことが成績を上 げることにつながると思われる。このことは小児中耳真 珠腫症では成人に比べ，有意に術後再含気化が良好で あったとの報告 ${ }^{15)}$ と一致する結果であった。 今回は 16 耳のうち 14 耳に真珠腫の再発・遺残の有無を点検するた めの 2 回目の手術を行った. 2 回目の手術で真珠腫の遺 残がみつかったのは 14 耳中 1 耳のみで, それもごく小さ なパール状真珠腫であったことから，1 回目の手術で真 珠腫が全摘できたという手ごたえがあれば経済的，時間 的な負担の大きい 2 回目の手術は省略できるように思わ
れる．この場合も術後の厳重な経過観察を行い，真珠腫 の再発が疑われる場合は積極的に試験的中耳開放術など を考える必要がある。

手術とともに術後の管理も非常に重要である，術後の 中耳の含気の促進や渗出性中耳炎の再発予防のために, 術中に挿入したチューブを中耳が安定するまで長期にわ たって留置する必要がある。このため, 定期的に厳重な 経過観察を行い，鼓膜チューブの閉塞や脱落があれば, 必要に応じて全身麻酔下鼓膜チューブ再挿入も考えるべ きと思われる。

\section{おわりに}

10 歳以下の 15 例 16 耳の癒着型真珠腫の手術成績を報 告した。

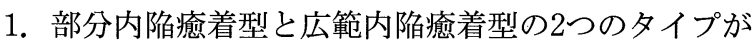
みられた。

2. 手術により 16 耳中 15 耳はほぼ正常な鼓膜所見, 中 耳腔となった。

3. 2 回目の手術での真珠腫の遺残は 14 耳中 1 耳のみ であった。

4. 術後の聴力成績も聴力測定のできた 15 耳中 13 耳 (87\%) が2000年の日本耳科学会の判定基準で成功となっ た.

以上のように良好な術後成績が得られたことから，幼 小児の癒着性真珠腫は病变が進行，陳旧化しないらちの 早目の手術が将来にわたってより危険の少ない安全な耳 にすることにつながると考えた.

\section{参考文献}

1）鈴木淳一：全中耳再建術一耳漏再開をみない手術法として の経耳管ドレナージュ・ベンチレーション法. 伝音性難聴 へのアプローチ (鈴木淳一編). $155 ＼mathrm{~ 165 ~ 頁 . ~ 篠 原 出 版, ~}$ 東京, 1983.

2）Tos M（訳者 大西俊郎）：渗出性中耳炎の後遺症.耳展 $30: 9 \sim 16,1987$.

3）栫 博幸：真珠腫性中耳炎. JOHNS $13: 227 \sim 232 ， 1997$.

4）小島博巳 : 鼓膜緊張部の菲薄化, 陥凹, 癒着化一上皮の増 殖・分化・緊張部真珠腫の発症機序一。Otol Jpn $9: 202$ 210，1999.

5）本多芳男：小児渗出性中耳炎の後遺症．耳鼻咽喉科・頭頸 部外科 MOOK $11: 215 \sim 224 ， 1989$.

6）森山 寛, 青木 基, 関 哲郎, 他 : 瘾着性中耳炎より緊 張部型真珠腫への移行型（前真珠腫）について。耳展 34 ： $39 \sim 45,1991$. 
7）中野雄一：各種真珠腫の名称を分類. 耳鼻咽喉科・頭頸部 外科 MOOK $16: 1 \sim 6,1990$.

8）高橋 姿：聴力改善困難な中耳炎の手術一癒着性中耳炎に ついて一. Otol Jpn 5:563〜 567, 1995.

9）森山 寛：聴力改善困難な手術一癒着性中耳炎一. Otol Jpn $5: 578 \sim 581,1995$.

10）森山 寛：癒着性中耳炎の治療. JOHNS $13: 1175 \sim 1179$, 1997.

11）森山 寬, 荒井秀一, 関 哲郎, 他: 瘉着性中耳炎一病態 と発症機転に関して一. 耳展 $37: 261 \sim 269,1994$.

12）牧野浩二, 稲葉順子, 東野哲也, 他: 癒着性中耳炎手術成 績の検討. Otol Jpn 5:26〜31，1995.

13）森山 寛:癒着性中耳炎の成因と手術的治療. 耳鼻臨床 89:
$147 \sim 152,1996$.

14）永瀬 大，松井和夫，小林 斉，他：癒着を伴う真珠腫性 中耳炎に対する鼻粘膜移植一移植部位の病理学的検討一. Otol Jpn $5: 227 \sim 231,1999$.

15）柿崎景子，佐々木祐佳子，飯野ゆき子，他：小児中耳真珠 腫症における鼓室形成術の再含気化について. Otol Jpn $13: 204 \sim 208,2003$.

原稿受付：平成16年 7 月 16 日

原稿採択: 平成16年11月 4 日 別刷請求先 : 児玉 章

厂410-0302 沼津市東椎路字春ノ木550 沼津市立病院耳鼻咽喉科 